\title{
HUBUNGAN PENGETAHUAN IBU YANG MEMILIKI ANAK PRASEKOLAH DENGAN TINDAKAN PERTOLONGAN PERTAMA PADA CEDERA
}

\author{
Niken Apdiningsih ${ }^{1}$, Sri Andala ${ }^{2}$, Novia Rizana $^{3}$ \\ ${ }^{1}$ Mahasiswa Program Studi Ilmu STIKes Muhammadiyah Lhokseumawe, Indonesia 24300 \\ ${ }^{2}$ Dosen Ilmu Keperawatan STIKes Muhammadiyah Lhokseumawe, Indonesia 24300 \\ ${ }^{3}$ Dosen Ilmu Keperawatan STIKes Muhammadiyah Lhokseumawe, Indonesia 24300 \\ *Correspondence : andalasri@gmail.com
}

\begin{abstract}
First aid is care given directly to people who are injured or suddenly sick. Injuries to children can be in the form of accidental or unintentional and intentional. Mother's knowledge about injuries and first aid measures in children is one the influencing factors. The purpose of the study was to determine the relationship between knowledge of mothers who have preschool-aged children and first aid measures for injuries. This study used an analytical design with a cross sectional approach. The number of the sample was 52 respondents using a total sampling technique. The research was carried out on 11 to 15 September 2021. The analysis was carried on by a computerized procces through the chi square test. The results of the statistical test showed that $\mathrm{p}$ value $=0.000<0.05$. This reveals that there is a relationship between mother's knowledge and first aid measures for injuries at Keude Lapang, Gandapura District, Bireuen. Therefore, it is suggested that mothers with preschool children having sufficient and less knowledge regarding first aids should increase their knowledge by participating in counseling and actively exchanging information regarding the issue with the closest people.
\end{abstract}

Keywords: Knowledge, First Aid, Injury, Preschool Children

\begin{abstract}
ABSTRAK
Pertolongan pertama merupakan perawatan yang diberikan secara langsung kepada orang terluka atau penyakit yang tiba-tiba. Cedera pada anak dapat berupa cedera yang tidak disengaja (unintentional injury) dan cedera yang disengaja (intentional injury). Pengetahuan ibu tentang cedera dan tindakan pertolongan pertama pada anak adalah salah satu faktor yang mempengaruhi. Tujuan penelitian adalah untuk mengetahui hubungan pengetahuan ibu yang memiliki anak usia prasekolah dengan tindakan pertolongan pertama pada cedera Desain penelitian bersifat analitik dengan pendekatan cross sectional dengan sampel 52 responden menggunakan teknik total sampling. penelitian dilaksanakan tanggal $11 \mathrm{~s} / \mathrm{d} 15$ September 2021. Analisa dilakukan dengan proses komputerisasi melalui uji chi square. Hasil uji statistik menunjukkan $p \_v a l u e=0,000<0,05$, Hal ini membuktikan bahwa ada hubungan pengetahuan ibu dengan tindakan pertolongan pertama pada cedera di Gampong Keude Lapang Kecamatan Gandapura Kabupaten Bireuen. Kesimpulan dari penelitian ini ada Hubungan Pengetahuan Ibu Yang Memiliki Anak Prasekolah Dengan Tindakan Pertolongan Pertama di Gampong Keude Lapang Kecamatan Gandapura Kabupaten Bireuen. Saran dari penelitian ini adalah Bagi ibu yang memiliki anak prasekolah dengan pengetahuan cukup dan kurang agar meningkatkan pengetahuan dengan mengikuti penyuluhan dan aktif bertukar informasi dengan orang terdekat.
\end{abstract}

Kata Kunci : Pengetahuan, Pertolongan Pertama, Cedera, Anak prasekolah 


\section{PENDAHULUAN}

Masa prasekolah merupakan masa keemasan (Golden Age) dimana stimulasi seluruh aspek perkembangan berperan penting untuk tugas perkembangan selanjutnya, dimana $80 \%$ perkembangan kognitif anak telah tercapai pada usia prasekolah (Septiani, Rizki. 2016). Perkembangan anak usia prasekolah pada saat anak berusia 3-5 tahun (Potter, Perry, Hall, \& Stockert, 2013). Berdasarkan Peraturan Bersama Menteri Pendidikan dan Kebudayaan Republik Indonesia dan Menteri Agama Republik Indonesia Nomor 2/VII/PB/2014 dengan Nomor 7 Tahun 2014 menyatakan satuan pendidikan anak usia dini pada jalur pendidikan formal yang menyelenggarakan program pendidikan bagi anak berusia 4-6 tahun. Usia anak prasekolah di Indonesia dimulai dari usia 36 tahun. (Renteng, Septiani. 2021).

Tahapan perkembangan pada anak usia prasekolah terdiri atas empat sektor yaitu perkembangan motorik kasar, motorik halus, personal sosial, dan kemampuan bahasa. Sektor motorik kasar yaitu kemampuan anak untuk melakukan gerakan sederhana hingga memiliki kemampuan dalam berlari (Santrock, 2011 dalam Renteng, Septiani. 2021). Sektor motorik halus yaitu kemampuan anak untuk mengambil objek kecil hingga menyusun benda dengan tepat serta koordinasi yang baik antara lengan, tubuh, tangan dan mata (Santrock, 2011 dalam Renteng, Septiani. 2021). Pada perkembangan sektor bahasa anak usia prasekolah yaitu kemampuan bahasa anak sebanyak 8000 kata- 14.000 kata yang digunakan anak untuk menentukan objek, menentukan warna, dan mengungkapkan keinginan (Potter, Perry, Hall, \& Stockert, 2013).

Sektor kemampuan personal sosial anak prasekolah dimana anak mulai untuk bersosialisasi dengan teman sebayanya. (Renteng, septiani. 2021). Anak usia prasekolah termasuk dalam kelompok risiko dengan tiga faktor yang mempengaruhi yaitu risiko dari biologi, risiko dari lingkungan sosial dan lingkungan fisik, serta risiko dari perilaku (Stanhope \& Lancaster, 2019). Berdasarkan risiko biologi pada anak usia prasekolah berkaitan dengan usia anak, karena masih dalam tahapan pertumbuhan dan perkembangan sehingga menyebabkan koordinasi motorik pada anak belum optimal dan berpengaruh terhadap kesehatan anak seperti beresiko terjadinya cedera (Potter, Perry, Hall, \& Stockert, 2013).

Pada umur tersebut anak sedang aktifnya, dimana anak mempunyai karakteristik seperti senang bermain, aktif bergerak, dan senang mencoba hal-hal baru. saat bermain anak dapat mengenal lingkungan, berinteraksi, serta mengembangkan emosi dan imajinasi dengan baik (Satya, 2006 dalam Endiyono \& Lutfiasari, 2016). Akan tetapi, pada masa ini sering terjadi kecelakaan pada anak sehingga diperlukan upaya pertolongan pertama. kejadian kecelakaan pada anak disekolah didapatkan data bahwa 34\% kematian disebabkan oleh kendaraan bermotor, $5 \%$ oleh jatuh, $4 \%$ oleh kebakaran, $13 \%$ oleh tenggelam, $21 \%$ oleh cedera tidak disengaja (WHO, 2005 dalam Endiyono \& Lutfiasari, 2016)

Menurut sensus yang dilakukan World Health Organization (WHO) diketahui 5,8 juta kematian di seluruh dunia diakibatkan karena cedera, dan lebih dari 3 juta kematian diantaranya ada negara-negara yang berkembang termasuk indonesia (Rizqiani, 2016). Penyebab terjadinya cedera pada anak salah satunya disebabkan oleh kelalaian atau kecerobohan dari orang tua yang terkadang tidak menyadari atau bahkan tidak mengetahui bahwa di rumah pun memiliki potensi yang dapat tejadi cedera pada anak. Cedera pada anak telah menjadi masalah kesehatan umum yang kejadiannya terus meningkat dan membutuhkan perhatian yang tinggi. Cedera di dunia bertanggung jawab sekitar 950.000 kematian tiap tahunnya pada anak usia dibawah 18 tahun. Hampir 90\% diantaranya disebabkan karena cedera yang tidak disengaja. Sekitar 230.000 kematian terjadi pada anak usia 5-14 tahun. Setiap tahun, puluhan juta anak membutuhkan perawatan karena cedera non-fatal, bahkan banyak diantarannya mengalami cacat seumur hidup. Setengah dari seluruh kematian akibat cedera yang tidak disengaja disebabkan oleh cedera lalu lintas dan 
tenggelam. (WHO, 2008 \& WHO, 2014 dalam lukita, puspitasari, asrie. 2021).

Berdasarkan Riskesdas

Prevalensi cedera pada anak di Indonesia pada tahun 2018 yaitu sebesar 9,2\% pravelensi ini terjadi peningkatan jika dibandingkan dengan tahun 2013 yaitu sebesar 8,2\% dan tahun 2007 yaitu sebesar $7,5 \%$. Cedera jatuh dan cedera kendaraan bermotor merupakan cedera yang paling sering terjadi yaitu dengan prevalensi masing-masing $40,9 \%$ dan $40,6 \%$. Pravelensi cedera pada anak di Jawa Barat khususnya Kota Bandung terdiri dari $42,1 \%$ Benturan, 28,3\% Luka lecet, terkilir 21,5\% dan di usia 5-14 tahun mencapai 11,5\% yang mengalami cedera dibanding usia lainnya (Riskesdas, 2007 dalam Lukita, Puspitasari, Asrie. 2021).

Di Indonesia upaya pemerintah untuk menurunkan angka kematian anak dengan mengikuti program berkelanjutan yang dikenal dengan Suitable Development Goals (SDGs) yang merupakan kelanjutan dari Milenium Development Goals (MDGs) yaitu sasaran keempat dengan tujuan menurunkan angka kematian ank, berbagai upaya yang dilaksankan dalam rangka meningkatkan kesehatan anak indonesia, yakni melalui continuum of care berdasarkan siklus hidup, continuum of care berdasarkan pelayanan kesehatan (promotif, preventif, kuratif, dan rehabilitatif), continuum of care pathway sejak ank di rumah, di masyarakat (pelayanan posyandu dan poskesdes), di fasilitas pelayanan kesehatan dasar, dan di fasilitas pelayanan kesehatan rujukan.(Novrianda, Dwi. Dkk. 2018).

Penanganan pertama yang tidak sempurna bisa berpotensi luka tadi makin parah. bahkan dikhawatirkan bisa sebagai kuman menginfeksi dalam luka dan menyebar ke semua tubuh, sebagai akibatnya membahayakan, yang berdampak dari suatu agen eksternal yang menimbulkan kerusakan baik fisik maupun mental (Jamil, 2017). Cedera biasanya berawal dari rasa keingintahuannya untuk menelusuri sesuatu dan bereksperimen yang tidak seimbang dengan kemampuan dalam memahami sesuatu atau bereaksi.
Upaya pencegahan mengurangi resiko keparahan cedera pada anak-anak dapat dilakukan dengan memberikan pertolongan pertama yang baik. Pertolongan pertama merupakan upaya untuk meminimalisir keparahan dan kecacatan seperti yang tercantum dalam UU 29 tahun 2014 tentang Pencarian dan Pertolongan, UndangUndang ini menyatakan bahwa pertolongan pertama adalah segala usaha dan kegiatan mencari, menolong, menyelamatkan, dan mengevakuasi manusia yang menghadapi keadaan darurat dan/atau bahaya dalam kecelakaan, bencana, atau kondisi membahayakan manusia. (Lukita, Puspitasari, Asrie. 2021).

Hasil penelitian Hastuti (2017) tentang hubungan pengetahuan orangtua tentang antisipasi cedera dengan praktik pencegahan cedera pada anak usia toddler di wilayah puskesmas jelekong didapatkan hasil, Ibu yang memiliki pengetahuan tentang antisipasi cedera akan menentukan tindakan pencegahan cedera, didapat dari hasil penelitian nya tentang antisipasi cedera dengan praktik pencegahan cedera pada anak usia toddler di kelurahan manggahang, bandung didapat hasil sebagian dari ibu (44,3\%) mempunyai pengetahuan cukup tentang antisipasi cedera pada anak usia toddler.

Hasil penelitian Aminah (2017) pada penelitian skripsi nya tentang pengaruh pendidikan kesehatan tentang P3K (Pertolongan Pertama Pada Kecelakaan) Terhadap Tingkat Pengetahuan Orang Tua Dalam Penanganan Cedera Anak Balita Di Rumah Tangga Di Desa Tunjungseto menunjukan bahwa pengetahuan orang tua sebelum diberikan pendidikan kesehatan dalam kategori cukup $(71,7 \%)$ kemudian sesudah diberikan pendidikan kesehatan berada dalam kategori baik (93,7\%). Pendidikan kesehatan menggunakan media slide power point, demondtrasi, dan pembagian leaflet sangat mempengaruhi pemahaman ibu tentang pertolongan pertama pada kecelakaan dalam penanganan cedera.

Pada penelitian yang dilakukan oleh Amalia Rizqiani (2016) tentang "Pengaruh Pendidikan Kesehatan First Aid Box Terhadap Tingkat Pengetahuan Orang tua 
Dalam Penanganan Cedera Anak Toddler Di Rumah Tangga" yang dilakukan di Tegalwangi Kasihan Bantu Yogyakarta hasilnya adalah ada pengaruh pendidikan kesehatan terhadap tingkat pengetahuan orang tua tentang First Aid Box.

Dari hasil pengambilan data awal yang dilakukan oleh peneliti di Gampong Keude Lapang dengan jumlah populasi masyarakat sebanyak 1345 jiwa, didapatkan hasil wawancara peneliti terhadap $10 \mathrm{ibu}$ yang memiliki anak prasekolah untuk mengetahui sejauh mana pengetahuan ibu dalam pertolongan pertama pada cedera didapatkan 3 ibu mengetahui tindakan pertolongan luka pada anak, 4 ibu mengetahui perawatan jatuh pada anak dan 3 orang lainnya tidak mengetahui bagaimana tindakan pertolongan pertama patah tulang yang dilakukan pada anak.

Berdasarkan Uraian diatas, maka penelti tertarik untuk melakukan penelitian tentang "Hubungan Pengetahuan Ibu Yang Memiliki Anak Prasekolah Dengan Tindakan Pertolongan Pertama Pada Cedera Di Gampong Keude Lapang Kecamatan Gandapura Kabupaten Bireuen"

\section{METODELOGI}

Penelitian ini menggunakan desain analitik dengan pendekatan cross sectional, Penelitian analitik yaitu penelitian yang menjelaskan adanya hubungan antara variabel bebas (independent) dengan variabel terikat (dependen) melalui pengujian hipotesa (Notoadmodjo, 2012). Adapun Penelitian analitik dalam penelitian ini adalah untuk mengetahui Hubungan Pengetahuan Ibu Yang Memiliki Anak Prasekolah Dengan Tindakan Pertolongan Pertama Pada Cedera Di Gampong Keude Lapang Kecamatan Gandapura Kabupaten Bireuen dengan pengamatan dan pengukuran dalam sekali waktu terhadap variabel bebas (independent) dan variabel terikat (dependen).

Populasi pada peneltian ini adalah ibu yang memiliki anak usia prasekolah 4-6 tahun dan bersekolah di Gampong Keude Lapang Kecamatan Gandapura Kabupaten bireuen sebanyak 52 orang.
Sampel dalam penelitian ini adalah total dari populasi yaitu sebanyak 52 orang. Pengambilan sampel dilakukan dengan teknik total sampling, dimana seluruh populasi yang ada diikutsertakan sebagai subjek penelitian.

Instrumen sebagai alat pengumpulan data dalam penelitian ini adalah angket kuesioner. lembaran kuesioner terdiri pernyataan positif dan negatif yang masing-masing berjumlah 20 pernyataan berisi variabel pengetahuan menggunakan skala guttman Dalam kuesioner ini terdapat pernyataan positif dan negatif yang memiliki 3 item indikator pernyataan yaitu memar, luka dan patah tulang. Pada indikator memar memiliki 6 item pernyataan dengan pernyataan positif (nomor : 1, 2, 3) dan pernyataan negatif (nomor 4, 5, 6). Pada indikator luka memiliki 8 item pernyataan dengan pernyataan positif (nomor 7,9,11,13) dan pernyataan negatif (nomor : $8,10,12,14$ ). Pada indikator patah tulang memiliki 6 item pernyataan dengan pernyataan positif (nomor $15,17,18$ ) dan pernyataan negatif (nomor 16,19,20). Kuesioner ini menggunakan skala guttman yang terdiri dari 2 (dua) alternative jawaban yaitu Pada pernyataan positif apabila responden menjawab benar nilainya (1) dan bila responden menjawab salah nilainya (0). Pada pernyataan negatif apabila responden menjawab benar nilainya (1) dan bila responden menjawab salah nilainya (0). dan variabel tindakan tentang pertolongan pertama dalam kuesioner memiliki 3 indikator pernyataan yaitu memar, luka dan patah tulang. Setiap pernyataan memiliki pernyataan positif sejumlah 10 item (nomor $1,3,6,8,9,11,13,15,17,19)$ dan negatif sejumalah 10 item (nomor $2,4,5,7,10,12,14,16,18,20)$. Kuesioner ini menggunakan Skala Likert dengan peryataan positif dengan skor jawaban SS $($ sangat setuju $)=5, \mathrm{~S}$ (setuju $)=4, \mathrm{RR}$ $($ ragu-ragu $)=3$, TS $($ tidak setuju $)=2$ dan STS (sangat tidak setuju) $=1$. Pada pernyataan negatif dengan skor jawaban SS $($ sangat setuju $)=1, \mathrm{~S}$ (setuju) $=2, \mathrm{RR}$ $($ ragu-ragu $)=3$, TS $($ tidak setuju $)=4$ dan STS $($ sangat tidak setuju $)=5$.

Sebelum instrument digunakan, 
peneliti melakukan uji instrument atau uji validitas dan reliabilitas pada 10 responden yang memiliki karakteristik yang sama di Gampong Ceubo Kecamatan Gandapura Kabupaten Bireuen.

Data yang dikumpulkan terlebih dahulu dengan mengurus surat izin penelitian dari STIKes Muhammadiyah Lhokseumawe, dan melakukan penelitian sesuai jadwal di Gampong Keude Lapang Kecamatan Gandapura Kabupaten Bireuen, Data diperoleh dengan pengisian kuesioner (wawancara terpimpin) untuk mendapatkan data pengetahuan ibu dengan tindakan pertolongan pertama pada cedera, selanjutnya data dianalisis.Setelah selesai pengumpulan data peneliti melakukan proses pengecekan, coding dan entry data. Selanjutnya dilakukan analisis data kuantitatif untuk menghasilkan distribusi frekuensi dan persentase dari tiap variabel, dan digunakan uji statistic chisquare untuk mengetahui hubungan pengetahuan ibu yang memiliki anak prasekolah dengan tindakan pertolonga pertama pada cedera

\section{HASIL PENELITIAN}

\section{Analisa Univariat}

a. Data demografi

Tabel 1. Distribusi Frekuensi Demografi $(\mathrm{n}=52)$

\begin{tabular}{|c|c|c|c|}
\hline No & $\begin{array}{l}\text { Karakteristik } \\
\text { Responden }\end{array}$ & Frekuensi & $\begin{array}{c}\text { Persentase } \\
(\%)\end{array}$ \\
\hline \multirow[t]{5}{*}{1} & Umur & & \\
\hline & 26-35 tahun & 28 & 53.8 \\
\hline & $36-45$ tahun & 17 & 32.7 \\
\hline & 46-55 tahun & 7 & 13.5 \\
\hline & Jumlah & 52 & 100 \\
\hline \multirow[t]{9}{*}{2} & Pendidikan & & \\
\hline & Tidak & 1 & 1.9 \\
\hline & Sekolah & 10 & 19.2 \\
\hline & SD & 5 & 9.6 \\
\hline & SMP & 30 & 57.7 \\
\hline & SMA & 6 & 11.5 \\
\hline & Perguruan & & \\
\hline & Tinggi & & \\
\hline & Jumlah & 52 & 100 \\
\hline \multirow[t]{5}{*}{3} & Pekerjaan & & \\
\hline & IRT & 22 & 42.3 \\
\hline & Petani & 6 & 11.5 \\
\hline & Pedagang & 15 & 28.8 \\
\hline & Pekerja & 6 & 11.5 \\
\hline
\end{tabular}

\begin{tabular}{lcc}
\hline $\begin{array}{l}\text { Swasta } \\
\text { PNS }\end{array}$ & 3 & 5.8 \\
\hline Jumlah & 52 & 100 \\
\hline
\end{tabular}

Berdasarkan tabel 1 dapat diketahui bahwa distribusi frekuensi mayoritas responden menurut umur yaitu antara 26-35 dengan 28 orang (53.8\%). Mayoritas pendidikan terakhir responden yaitu SMA sebanyak 30 orang $(57.7 \%)$. Mayoritas pekerjaan responden yaitu IRT sebanyak 22 orang $(42.3 \%)$.

Tabel 2. Pengetahun $(\mathrm{n}=52)$

\begin{tabular}{clcc}
\hline NO & Pengetahuan & Frekuensi & Persentase(\%) \\
\hline 1 & Baik & 17 & 32.7 \\
2 & Cukup & 22 & 42.3 \\
3 & Kurang & 13 & 25 \\
\hline & Jumlah & 52 & 100 \\
\hline
\end{tabular}

Berdasarkan tabel 2 dapat disimpulkan bahwa pengetahuan ibu tentang tindakan pertolongan pada cedera yang memiliki pengetahuan pada kategori baik sebanyak 17 responden $(32,7 \%)$, pada kategori cukup sebanyak 22 responden (42,3\%), pada kategori kurang sebanyak 13 responden $(25 \%)$

Tabel 3. Tindakan Pertolongan $(n=52)$

\begin{tabular}{clcc}
\hline NO & Tindakan & Frekuensi & Persentase $(\%)$ \\
\hline 1 & Baik & 16 & 30.8 \\
2 & Cukup & 21 & 40.4 \\
3 & Kurang & 15 & 28.8 \\
\hline & Jumlah & 52 & 100 \\
\hline
\end{tabular}

Berdasarkan tabel 3. dapat disimpulkan bahwa Tindakan Ibu Tentang Pertolongan Pertama Pada pada kategori baik sebanyak 16 responden $(30.8 \%)$, pada kategori cukup sebanyak 21 responden (40.4\%), pada kategori kurang sebanyak 15 orang responden $(28.8 \%)$.

\section{Analisa Bivariat}

Hubungan Pengetahuan Dengan
Tindakan Pertolongan Pertama Pada
Cedera


Tabel 4. Hubungan Pengetahuan Dengan Tindakan Pertolongan Pertama Pada Cedera $(\mathrm{N}=52)$

\begin{tabular}{|c|c|c|c|c|c|c|c|c|c|c|c|}
\hline \multirow{3}{*}{ No } & \multirow{3}{*}{ Pengetahauan } & \multicolumn{6}{|c|}{ Tindakan Pertolongan } & \multirow{2}{*}{\multicolumn{2}{|c|}{ Total }} & \multirow{3}{*}{$\begin{array}{c}\text { Chi } \\
\text { Square }\end{array}$} & \multirow{3}{*}{$\begin{array}{l}P . \\
\text { Value }\end{array}$} \\
\hline & & \multicolumn{2}{|c|}{ Baik } & \multicolumn{2}{|c|}{ Cukup } & \multicolumn{2}{|c|}{ Kurang } & & & & \\
\hline & & $\mathrm{F}$ & $\%$ & F & $\%$ & $F$ & $\%$ & $\mathrm{~F}$ & $\%$ & & \\
\hline 1 & Baik & 12 & 70.6 & 3 & 17.6 & 2 & 11.8 & 17 & 32.7 & \multirow{4}{*}{0,05} & \multirow{4}{*}{0,000} \\
\hline 2 & Cukup & 3 & 13.6 & 17 & 77.3 & 2 & 9.1 & 22 & 42.3 & & \\
\hline 3 & Kurang & 1 & 7.7 & 1 & 7.7 & 11 & 84.6 & 13 & 25 & & \\
\hline 4 & Total & 16 & 30.8 & 21 & 40.4 & 15 & 28.8 & 52 & 100 & & \\
\hline
\end{tabular}

Hasil penelitian menunjukkan bahwa dari $17 \quad(32,7 \%)$ responden yang mempunyai pengetahuan baik dengan tindakan baik sebanyak $12 \quad(70,6 \%)$ responden, Responden yang pengetahuan baik dengan tindakan cukup sebanyak 3 (17.6\%) responden, dan responden yang pengetahuan baik dengan tindakan kurang sebanyak $2(11,8 \%)$ responden. Dari 22 $(42,3 \%)$ responden yang mempunyai pengetahuan cukup dengan tindakan baik sebanyak $3(13,6 \%)$ responden, Responden yang pengetahuan cukup dengan tindakan cukup sebanyak 17 (77,3\%) responden, dan responden yang pengetahuan cukup dengan tindakan kurang sebanyak $2 \quad(9,1 \%)$ responden. Dari 13 (25\%) responden yang mempunyai pengetahuan kurang dengan tindakan baik sebanyak $1 \quad(7,7 \%)$ responden, responden yang mempunyai pengetahuan kurang dengan tindakan cukup sebanyak $1 \quad(7,7 \%)$ responden dan responden yang mempunyai pengetahuan kurang dengan tindakan kurang $11(84,6 \%)$ responden.

Hasil uji statistik menunjukkan bahwa $p_{\text {_value }}=0,000<0,05$, Hal ini membuktikan bahwa ada hubungan pengetahuan ibu dengan tindakan pertolongan pertama pada cedera di Gampong Keude Lapang Kecamatan Gandapura Kabupaten Bireuen.

\section{PEMBAHASAN}

\section{Hubungan Pengetahuan Dengan Tindakan Pertolongan Pertama Pada Cedera}

Berdasarkan hasil penelitian dalam hasil analisa bivariate yang dilakukan untuk mengukur hubungan pengetahuan ibu yang memiliki anak prasekolah dengan tindakan pertolongan pertama pada cedera di menunjukkan bahwa dari $17 \quad(32,7 \%)$ responden yang mempunyai pengetahuan baik dengan tindakan baik sebanyak 12 $(70,6 \%)$ responden, Responden yang pengetahuan baik dengan tindakan cukup sebanyak $3(17.6 \%)$ responden, dan responden yang pengetahuan baik dengan tindakan kurang sebanyak 2 (11,8\%) responden. Dari $22(42,3 \%)$ responden yang mempunyai pengetahuan cukup dengan tindakan baik sebanyak $3 \quad(13,6 \%)$ responden, Responden yang pengetahuan cukup dengan tindakan cukup sebanyak 17 (77,3\%) responden, dan responden yang pengetahuan cukup dengan tindakan kurang sebanyak $2(9,1 \%)$ responden. Dari 13 $(25 \%)$ responden yang mempunyai pengetahuan kurang dengan tindakan baik sebanyak $1(7,7 \%)$ responden, responden yang mempunyai pengetahuan kurang dengan tindakan cukup sebanyak $1(7,7 \%)$ responden dan responden yang mempunyai pengetahuan kurang dengan tindakan kurang $11(84,6 \%)$ responden.

Hasil uji statistik menunjukkan bahwa $p_{\text {_value }}=0,000<0,05$, Hal ini membuktikan bahwa ada hubungan pengetahuan ibu dengan tindakan pertolongan pertama pada cedera.

$$
\text { Menurut Nasution (2016) }
$$
mengatakan bahwa pengetahuan adalah pokok penting yang muncul dari buah pikir manusia itu sendiri. Konsep dari pengetahuan sendiri memiliki sifat yang meluas, evaluative, agensial dan objektif. Pengetahuan terkait pertolongan pertama sangat penting sebagai upaya sederhana yang dilakukan secara akurat sesuai dengan jenis cedara yang terjadi dengan pemberian intervensi kecil secara tepat waktu dan benar akan menyelamatkan hidup seseorang tersebut, tetapi jika intervensi dilakukan dengan tidak semestinya dapat merugikan nyawa orang atau bahkan dapat menyebabkan gangguan irreversible (Keles, Aydin, 2015).

Faktor-faktor yang mempengaruhi pengetahuan seseorang yaitu terbagi 
menjadi faktor internal dan eksternal. faktor internal diantaranya yaitu pendidikan, pekerjaan, umur. Sedangkan faktor eksternal diantaranya yaitu lingkungan dan sosial budaya. (wiharjo, 2019). Pengetahuan merupakan hasil dari tahu dan tindakan dari mengingat suatu hal serta akan terjadi bila seseorang melakukan pengamatan terhadap suatu objek tertentu (Alfianur, 2020). Pengetahuan yang baik dalam bisa dipengaruhi oleh beberapa faktor yaitu faktor internal dan eksternal. Faktor internal meliputi umur, intelegensi dan alat indra (Alfianur, 2020).

Pengetahuan ibu sangat penting karena dengan pengetahuan yang baik maka ibu dapat memilih tindakan yang tepat untuk memberikan pertolongan pada anaknya. Apabila tindakan yang dipilih ibu tidak tepat maka akan menimbulkan masalah kesehatan yang serius dan berunjung kematian pada anak. Bila kasus ringan hingga sedang maka bisa diatasi sendiri oleh ibu sehingga peran ibu sangat penting yaitu memberikan tindakan pertolongan pada anak dengan tepat. Bila kasusnya parah dan mungkin bisa mengancam nyawa, maka ibu harus segera mengambil tindakan agar anaknya mendapatkan pertolongan medis dan segera di bawa ke rumah sakit, karena jika pengetahuan baik, maka ibu akan mengetahui cara melakukan pertolongan pertama anak sakit di rumah dengan tepat dan ibu akan membawa anak berobat atau merujuk ke saranan kesehatan.

Tindakan merupakan suatu teori dalam memahami tindakan yang perlu dilakukan untuk mendapatkan hasil yang diinginkan dalam suatu keadaan. Ketika tindakan sudah menjadi kebiasaan, maka secara otomatis tindakan itu akan selalu dijalankan. Namun ketika tindakan sudah tidak efektif maka akan muncul kepedulian pada teori tindakan serta usahan untuk memperbaikinya (Johnson, 2012). Pertolongan pertama adalah pemberian pertolongan segera kepada penderita sakit atau cidera yang memerlukan medis dasar, medis dasar yang dimaksudkan disini adalah tindakan perawatan berdasarkan ilmu kedokteran yang dapat dimiliki orang awam, Faktor-faktor yang mempengaruhi pertolongan pertama yaitu pengetahuan, pengalaman, dan kematangan atau sifak kedewasaan (Wiharjo, 2019).

Pada penelitian Hatimah, (2019) dengan judul Hubungan Pengetahuan Orang Tua Dengan Self-Efficacy Dalam Melakukan Pertolongan Pertama Pada Cedera Anak Usia Prasekolah, hasil dari penelitian yang didasarkan pada data dari 53 responden dianalisa menggunakan produk Pearson moment korelasi tes korelasi, memperoleh nilai yang signifikan $(\mathrm{p}=0.001)$ dan sebuah korelasi nilai tambahan $(\mathrm{r}=0.428)$ yang menunjukkan hubungan antara pengetahuan dan selfefficacy di perawatan pertama di TK. Kebanyakan orang tua mendapatkan informasi tentang pertolongan pertama dari media massa dan beberapa dari pekerja kesehatan. Informasi yang diperoleh dari pekerja kesehatan dan pemahaman yang benar, akan positif mempengaruhi efektivitas diri orang tua dalam melakukan pertolongan pertama.

Pada penelitian yang dilakukan Hastuti (2017) dengan judul Hubungan Pengetahuan Tentang Antisipasi Cedera Dengan Praktik Pencegahan Cedera Pada Anak Usia Toddler Di Rw 01 Kelurahan Manggahang Wilayah Puskesmas Jelekong Kabupaten Bandung. Hasil penelitian menunjukkan sebagian ibu berpengetahuan cukup tentang antisipasi cedera (44,3\%). Hasil uji Chi-Square diperoleh adanya hubungan antara pengetahuan ibu tentang antisipasi cedera dengan praktik pencegahan cedera pada anak usia toddler di RW $01(\mathrm{P}$ value $=0,000)$. Disarankan para ibu untuk meningkatkan pengetahuan tentang antisipasi cidera sehingga ibu dapat melakukan tindakan dalam menjamin kesehatan, keamanan, dan keselamatan anak dalam beraktifitas sehingga anak terhindar dari bahaya cedera.

Hasil penelitian Aminah (2017) pada penelitian nya tentang pengaruh pendidikan kesehatan tentang P3K (Pertolongan Pertama Pada Kecelakaan) Terhadap Tingkat Pengetahuan Orang Tua Dalam Penanganan Cedera Anak Balita Di Rumah Tangga Di Desa Tunjungseto menunjukan bahwa pengetahuan orang tua sebelum diberikan pendidikan kesehatan dalam 
kategori cukup $(71,7 \%)$ kemudian sesudah diberikan pendidikan kesehatan berada dalam kategori baik $(93,7 \%)$. Pendidikan kesehatan menggunakan media slide power point, demondtrasi, dan pembagian leaflet sangat mempengaruhi pemahaman ibu tentang pertolongan pertama pada kecelakaan dalam penanganan cedera.

Pada penelitian yang dilakukan oleh Amalia Rizqiani (2016) tentang "Pengaruh Pendidikan Kesehatan First Aid Box Terhadap Tingkat Pengetahuan Orang tua Dalam Penanganan Cedera Anak Toddler Di Rumah Tangga" yang dilakukan di Tegalwangi Kasihan Bantu Yogyakarta didapatkan Hasil uji statistik tingkat pengetahuan dengan rancangan pre-testpost-test kelompok kontrol tentang pengetahuan komponen first aid box dan penanganan cedera anak toddler diperoleh nilai yang signifikan $0,000 \quad(\mathrm{p}<0,05)$, sedangkan pada kelompok intervensi juga didapatkan hasil yang signifikan 0,000 $(\mathrm{p}<0,05)$. Hasil uji statistik Independent TTest pada posttest kelompok control dan intervensi diperoleh nilai probabilitas sig. (2-tailed) sebesar $0,000 \quad(p<0,05)$. Kesimpulan: ada pengaruh pendidikan kesehatan terhadap tingkat pengetahuan orang tua.

Hasil penelitian menunjukkan bahwa pengetahuan yang bervariasi memperngaruhi tindakan responden. Berdasarkan hasil penelitian, mayoritas responden memiliki tingkat pengetahuan cukup 22 (42,3\%). Hal ini sejalan dengan teori Notoatmojo bahwa tindakan yang baik dapat dipengaruhi oleh pengetahuan yang adekut.

Asumsi peneliti, pengetahun yang baik berpengaruh pada tindakan pertolongan yang dilakukan ibu hal ini sesuai dengan penelitian Pada penelitian Echa Effendi Siswanto Amir (2018) dengan hasil penelitian yang didapatkan bahwa pengetahuan orang tua sebagian besar baik sehingga Kejadian cedera pada anak toddler yang berobat sebagian besar tidak berulang.

\section{KESIMPULAN}

Berdasarkan hasil penelitian, mayoritas responden memiliki pengetahuan pada kategori cukup sebanyak $22(42,3 \%)$ dan hasil tindakan pertolongan pertama pada cedera responden pada kategori cukup sebanyak 21 (40.4\%). pengetahun yang baik berpengaruh pada tindakan pertolongan yang dilakukan ibu.

Berdasarkan hasil penelitian yang dilakukan peneliti dengan sampel 52 ada "hubungan pengetahuan ibu yang memiliki anak prasekolah dengan tindakan pertolongan pertama pada cedera di Gampong Keude Lapang Kecamatan Gandapura Kabupaten Bireuen" peneliti menyimpulkan ada hubungan pengetahuan ibu dengan tindakan pertolongan pertama pada cedera

\section{Ucapan Terima Kasih}

a. Ketua STIKes Muhammadiyah Lhokseumawe Ns. Mursal.

b. Kepala klinik bersalin Hj. Rosdiana, S.SiT yang telah memberikan izin penelitian sehingga penelitian terlaksana dengan baik.

\section{DAFTAR PUSTAKA}

Alfianur, A. 2020. Pengetahuan Tentang Covid $19 \quad$ Mahasiswa Keperawatan Universitas Borneo Tarakan. Journal of Borneo Holistic Health, 3(2).

Aminah, Cahya. 2017. Pengaruh pendidikan kesehatan tentang p3k (pertolongan pertama pada kecelakaan) terhadap tingkat pengetahuan orang tua dalam penanganan cedera anak balita di rumah tangga di desa tunjungseto kecamatan sempor. Skripsi Program Studi Ilmu Keperawatan STIKes Muhammadiyah Gombong.

Echa Effendi Siswanto Amir. 2018. Hubungan Pengetahuan Orang Tua Dengan Kejadian Cedera Pada Anak Usia Toddler Yang Berobat Di Wilayah Kerja Puskesmas Passi Barat, Graha Medika Nursing Journal: Vol. 1 No. 1 : Graha Medika Nursing Journal. 
Endiyono, arum lutfiasari. 2016. Pendidikan kesehatan pertolongan pertama berpengaruh terhadap tingkat pengetahuan dan praktek guru dalam penanganan cedera pada siswa di sekolah dasar. Jurnal ilmiah ilmu-ilmu kesehatan, Vol. 14 No.1

Hastuti, D. 2017. Hubungan pengetahuan tentang antisipasi cedera dengan praktik pencegahan cedera pada anak usia toddler di rw 01 kelurahan manggahang wilayah puskesmas jelekong kabupaten bandung. Jurnal Keperawatan Komprehensif Vol.3 No.1, Hal. 52-62.

Hatimah, Husnul. 2019. Hubungan pengetahuan orang tua dengan self-efficacy dalam melakukan pertolongan pertama pada cedera anak usia prasekolah. Skripsi Program Studi Ilmu Keperawatan Universitas Muhammadiyah Malang.

Jamil, Mokhtar. 2017. Penanganan Kedaruratan Sehari-Hari Pada Anak Usia Dini di Rumah. Purwokerto: IRDH.

Johnson, D. W. and Johnson, F.P., 2012. Dinamika kelompok teori dan keterampilan edisi 9, PT. Indeks, Jakarta,pp. 49.

Keles, P. U.,Yildirim, Z., \& Aydin, S. 2015. Determining the basic first-aid knowledge levels of the class teachers working in the city center of agri. Journal of emerging trends in educational research and polcy studies, 6(6),404-410.

Lukita, Puspitasari, Asrie. 2021. Pendidikan Kesehatan pada Guru tentang Pertolongan Pertama dalam Penanganan Cedera pada Anak
Usia Pra-Sekolah. Bina Sehat

Masyarakat Vol.1 No.1

Nasution, A. T. 2016. Filsafat ilmu : hakikat mencari pengetahuan. Yogyakarta : Deepublish.

Notoatmodjo,S. 2012. Metodologi penelitian kesehatan. Jakarta : PT.Rineka Cipta

Novrianda, Dwi. Dkk. 2018. Diseminasi ilmu pertolongan pertama kecelakaan pada anak di rumah pada wilayah kerja puskesmas ambacang._Jurnal hilirisasi IPTEKS Vol. 1 No. 1

Potter, P. A., Perry, A. G., Stockert, P., \& Hall, A. 2013. Fundamentals of nursing, 8th edition. In Notes.

Renteng, Septriani. 2021. Stimulasi perkembangan pada anak usia prasekolah. Jurnal Ilmiah Indonesia Vol. 6, No. 3.

Riset Kesehatan Dasar. 2018. Badan penelitian dan pengembangan kesehatan. Departemen Kesehatan : Republik Indonesia.

Rizkqiani, A. 2016. Pengaruh pendidikan kesehatan first aid box terhadap tingkat pengetahuan orang tua dalam penanganan cedera anak toddler di rumah tangga. Naskah Publikasi. Yogyakarta : Universitas -

Muhammadiyah Yogyakarta.

Septiani, Rizki.dkk. 2016. Tingkat perkembangan anak pra sekolah usia 3-5 tahun yang mengikuti dan tidak mengikuti pendidikan anak usia dini (PAUD). Jurnal Keperawatan Jiwa, Volume 4 No 2, Hal 114125.

Wiharjo, Oetamiati ami. 2019. Hubungan Tingkat Pengetahuan Orangtua 
Pertolongan Pertama Kejang

Demam Pada Anak Usia Balita

Di Ruang Aster Rsud Kota

Bogor. Jurnal Ilmiah Wijaya

Volume 11 Nomor 2 